DOI: $10.15193 /$ zntj/2019/120/304

\author{
DOROTA ZIELIŃSKA, ALEKSANDRA SZYDŁOWSKA, ANNA ŁEPECKA, \\ DANUTA KOŁOŻYN-KRAJEWSKA
}

\title{
WPLYW WYBRANYCH SKŁADNIKÓW ŻYWNOŚCI NA ZACHOWANIE ŻYWOTNOŚCI BAKTERII LACTOBACILLUS SPP. W PRZEWODZIE POKARMOWYM - BADANIA IN VITRO
}

\begin{abstract}
Streszczenie
Celem badań była ocena przeżywalności wybranych szczepów bakterii Lactobacillus wyizolowanych z sera oscypkowego i korycińskiego w warunkach in vitro modelu przewodu pokarmowego w zależności od zastosowanych dodatków żywnościowych. Zakres prac obejmował ocenę przeżywalności bakterii po 2 i 5 h inkubacji w modelowym układzie symulującym pasaż żołądkowo-jelitowy w zależności od zastosowanego dodatku ochronnego: mleka UHT (o zawartości thuszczu 3,2 \%), śmietanki (o zawartości tłuszczu $36 \%$ ), a także 10-procentowych roztworów inuliny i oligofruktozy. Wykazano, że badane szczepy były oporne na sok żołądkowy o $\mathrm{pH}=2,5$, natomiast model soku żołądkowego o $\mathrm{pH}=2$ powodował zmniejszenie żywotności bakterii średnio o ok. 5 rzędów logarytmicznych po $2 \mathrm{~h}$ inkubacji. Mleko UHT wykazało nieznaczne działanie ochronne na przeżywalność komórek bakterii, porównywalne do inuliny i oligofruktozy w środowisku obniżonego $\mathrm{pH}$, przy zastosowanej metodzie badawczej. Istotny efekt ochronny na przeżywalność komórek bakterii badanych szczepów stwierdzono natomiast w przypadku zastosowania śmietanki, co najprawdopodobniej ma związek z większą zawartością thuszczu w porównaniu z jego zawartością w mleku. Badane szczepy Lb. plantarum (Kor1 oraz Os1) wyizolowane z żywności charakteryzowały się podobnymi właściwościami jak szczep referencyjny Lb. plantarum 299v, co świadczyć może o potencjalnych właściwościach probiotycznych w tym zakresie. Przeprowadzone badania wskazują na zasadność dalszych badań potwierdzających probiotyczne właściwości i potencjalne zastosowanie jako probiotyków bakterii wyizolowanych z żywności fermentowanej.
\end{abstract}

Słowa kluczowe: probiotyki, Lactobacillus, badania in vitro, przewód pokarmowy, przeżywalność

\section{Wprowadzenie}

Sprawnie działający ekosystem jelitowy, tzw. mikrobiota (skład ilościowy i jakościowy różnych mikroorganizmów) ma duży wpływ na zachowanie zdrowia człowie-

Dr inż. D. Zielińska, dr inż. A. Szydłowska, dr inż. A. Łepecka, prof. dr hab. D. Kołożyn-Krajewska, Katedra Technologii Gastronomicznej i Higieny Żywności, Wydz. Nauk o Żywieniu Człowieka i Konsumpcji, Szkoła Główna Gospodarstwa Wiejskiego w Warszawie, ul. Nowoursynowska 159 C, 02-776 Warszawa.Kontakt:dorota_zielinska@sggw.pl 
ka. Mikrobiota jelit człowieka jest najbardziej zróżnicowanym gatunkowo ekosystemem na ziemi (100 - 1000 gatunków). Ze względu na rosnącą świadomość roli układu mikrobioty jelitowej dla zachowania zdrowia człowieka od ponad 20 lat na całym świecie prowadzone są prace badawcze związane z możliwościami pozytywnej modyfikacji lub wzbogacenia mikrobioty człowieka. Duże nadzieje wiąże się z zastosowaniem probiotyków i prebiotyków [14].

Najczęściej spotykanymi rodzajami probiotyków są Bifidobacterium spp. i Lactobacillus spp. Za probiotyczne uważane są także wybrane szczepy drożdży Saccharomyces boulardii. Mikroorganizmy, aby mogły zostać zaklasyfikowane do szczepów probiotycznych, powinny zostać precyzyjnie zdefiniowane poprzez określenie odpowiednich kryteriów dotyczących bezpieczeństwa stosowania, cech funkcjonalnych oraz technologicznych. Mikroorganizmy - kandydaci do miana „probiotyku” - muszą spełnić trzy kluczowe wymagania: (1) muszą być żywe w momencie podania i muszą być mikroorganizmami, (2) muszą być podane w dawce wystarczająco wysokiej, aby wywołać efekt prozdrowotny, (3) muszą wywierać korzystny wpływ na gospodarza [6, 23]. Do niedawna szczepy bakterii probiotycznych izolowano jedynie z przewodu pokarmowego zdrowych ludzi. W ostatnich latach rośnie zainteresowanie nowymi szczepami, wyizolowanymi z innych, niekonwencjonalnych źródeł, które także są w stanie przetrwać trudne warunki panujące $\mathrm{w}$ przewodzie pokarmowym człowieka [25]. Wśród najtrudniejszych barier do pokonania podczas trawienia pokarmu wyróżnia się niskie wartości $\mathrm{pH}$ panujące $\mathrm{w}$ żołądku, aktywność enzymów trawiennych, a także obecność soli kwasów żółciowych [3, 13, 22]. Czynnikami, które mogą wpływać ochronnie na przeżywalność bakterii są składniki żywności, w tym prebiotyki, czyli składniki pokarmowe niezdolne do życia, wywierające pozytywny wpływ na zdrowie gospodarza, zważywszy na modulację zespołu mikroorganizmów w jelicie [7]. Prebiotyki nie są trawione przez enzymy endogenne przewodu pokarmowego człowieka, trafiają w stanie nienaruszonym do okrężnicy, gdzie ulegają fermentacji, stanowiąc pożywkę dla mikroorganizmów probiotycznych. Ponadto prebiotyki są rozkładane przez bakterie sacharolityczne obecne $\mathrm{w}$ dolnym odcinku przewodu pokarmowego i mają zdolność stymulacji ich wzrostu. Inulina i oligofruktoza są najczęściej stosowanymi i najbardziej efektywnymi prebiotykami [17].

Celem pracy była ocena przeżywalności wybranych szczepów bakterii Lactobacillus plantarum wyizolowanych z oscypka i sera korycińskiego w warunkach in vitro modelu przewodu pokarmowego, w zależności od zastosowanych dodatków żywnościowych, w tym prebiotyków.

\section{Material i metody badań}

Materiałem do badań były trzy szczepy bakterii fermentacji mlekowej gatunku Lactobacillus plantarum, które zostały wyizolowane z serów: oscypka (szczep Os1) 
i korycińskiego (szczep Kor1) [20] oraz referencyjny szczep Lactobacillus plantarum 299v o potwierdzonych klinicznie właściwościach probiotycznych. Bakterie Lactobacillus hodowano na podłożu MRS (LabM, Wielka Brytania) i określano ich liczbę zgodnie z PN-ISO 15214:2002 [21]. Model trawienny in vitro symulujący pasaż żołądkowo-jelitowy wykonano $\mathrm{z}$ dwóch roztworów soków trawiennych, które stosowano sekwencyjnie. Czas trwania trawienia w soku żołądkowym wynosił $2 \mathrm{~h}$, a w soku jelitowym $-3 \mathrm{~h}$, w temp. $37{ }^{\circ} \mathrm{C}$ [22]. Skład soków żołądkowego i jelitowego podano w tab. 1.

Tabela 1. Składniki soków żołądkowego i jelitowego użytych w badaniu

Table 1. Composition of gastric and intestinal juices used in experiment

\begin{tabular}{|c|c|}
\hline Rodzaj soku / Type of juice & Skład soku / Composition of juice \\
\hline Sok żołądkowy / Gastric juice & $\begin{array}{l}\text { 0,5-procentowy roztwór } \mathrm{NaCl} / 0.5 \% \mathrm{NaCl} \text { solution } \\
\text { Lizozym }(1 \mathrm{~g} / \mathrm{l}) / \text { Lisozyme }(1 \mathrm{~g} / \mathrm{l}) \\
\text { Pepsyna }(0,3 \mathrm{~g} / 1) / \text { Pepsin }(0.3 \mathrm{~g} / \mathrm{l}) \\
5 \mathrm{M} \mathrm{HCl}(\mathrm{w} \text { celu uzyskania właściwego } \mathrm{pH} 2,5 \text { lub } 2,0) \\
5 \mathrm{M} \mathrm{HCl} \text { (in order to obtain proper } \mathrm{pH} \text { of } 2.5 \text { or of } 2.0)\end{array}$ \\
\hline Sok jelitowy / Intestinal juice & $\begin{array}{l}\text { Roztwór } \mathrm{NaHCO}_{3}(6,4 \mathrm{~g} / \mathrm{l}) / \mathrm{NaHCO} \mathrm{Na}_{3}(6.4 \mathrm{~g} / \mathrm{l}) \text { solution } \\
\mathrm{KCl}(0,239 \mathrm{~g} / \mathrm{l}) / \mathrm{KCl}(0.239 \mathrm{~g} / \mathrm{l}) \\
\mathrm{NaCl}(1,28 \mathrm{~g} / \mathrm{l}) / \mathrm{NaCl}(1.28 \mathrm{~g} / 1) \\
\text { Pankreatyna }(1 \mathrm{~g} / 1) / \text { Pancreatin }(1 \mathrm{~g} / \mathrm{l}) \\
\text { Żółć wołowa }(0,3 \%) / \text { Bovine bile }(0.3 \%)\end{array}$ \\
\hline
\end{tabular}

Wszystkie odczynniki pochodziły z firmy Sigma Aldrich, Polska / All chemicals were from Sigma Aldrich Co, Poland.

W badaniach uwzględniono sześć wariantów doświadczalnych:

1. Warunki standardowe $-\mathrm{pH}$ soku żołądkowego wynosiło 2,5 .

2. Warunki standardowe $-\mathrm{pH}$ soku żołądkowego obniżono do wartości 2,0.

3. Warunki standardowe (2) $-\mathrm{z}$ dodatkiem czynnika ochronnego w postaci mleka UHT 3,2 \% (Mlekovita, Polska).

4. Warunki standardowe (2) $-\mathrm{z}$ dodatkiem czynnika ochronnego w postaci śmietanki UHT $36 \%$ (Mlekovita, Polska).

5. Warunki standardowe (2) - z dodatkiem czynnika ochronnego w postaci 10-procentowego roztworu inuliny (Frutafit, Sensus, Holandia).

6. Warunki standardowe (2) - z dodatkiem czynnika ochronnego w postaci 10-procentowego roztworu oligofruktozy (Raftilose P95, Orafti, Belgia).

Każdorazowo po $1 \mathrm{ml}$ hodowli Lactobacillus (gęstość populacji ok. $\left.1 \times 10^{9} \mathrm{jtk} / \mathrm{ml}\right)$ odwirowywano $(6000 \times \mathrm{g}, 10 \mathrm{~min})$, zlewano supernatant, płukano roztworem soli fizjologicznej PBS (Sigma Aldrich, Polska) i dodawano po $5 \mathrm{ml}$ soku żołądkowego. W wariantach 3, 4, 5 i 6 dodawano po $50 \mu 1$ czynnika ochronnego (mleka, śmietanki, inuliny lub oligofruktozy), a w wariantach 1 i 2 po $50 \mu$ PBS i pipetowano 
przez 3 min w celu wymieszania z komórkami bakterii przed zawieszeniem w soku żołądkowym. Następnie próbki poddawano inkubacji przez $2 \mathrm{~h}$ w temp. $37{ }^{\circ} \mathrm{C}$, po czym odwirowywano $(6000 \times \mathrm{g}, 10 \mathrm{~min})$, zlewano supernatant, dodawano po $10 \mathrm{ml}$ soku jelitowego i inkubowano przez $3 \mathrm{~h} \mathrm{w}$ temp. $37^{\circ} \mathrm{C}$. Badania mikrobiologiczne wykonywano w czasie 0 , po 2 i $5 \mathrm{~h}$ inkubacji, w trzech powtórzeniach.

Analizę statystyczną przeprowadzono w programie Statistica 13 (StatSoft, Polska). Zastosowano jednoczynnikową analizę wariancji ANOVA (przy p $<0,05$ ), a także analizę składowych głównych PCA (Principal Component Analysis).

\section{Wyniki i dyskusja}

W celu stwierdzenia, że dany szczep wykazuje korzystne działanie na zdrowie człowieka, trzeba w pierwszej kolejności stwierdzić, czy pokonuje barierę żołądkowojelitową. Czynnikami, które ograniczają szanse przeżycia bakterii w trakcie trawienia, są: niskie pH, obecność soli kwasów żółciowych oraz enzymów. W tab. 2. przedstawiono wyniki badań przeżywalności bakterii Lactobacillus w układzie doświadczalnym.

Pierwszy model doświadczalny (1) został zaczerpnięty z badań przeprowadzonych przez Rzepkowską i wsp. [22]. Odczyn pH soku żołądkowego wynosił 2,5, natomiast stężenie soli żółciowych wynosiło 0,3 \%. Ponadto do soków trawiennych zastosowano dodatek enzymów (tab. 1). W tych warunkach liczba komórek bakterii obniżyła się średnio o $1 \log$ jtk/ml po $2 \mathrm{~h}$ inkubacji w soku żołądkowym, z wyjątkiem szczepu Os1, w przypadku którego redukcja liczby sięgała $0,4 \log \mathrm{jtk} / \mathrm{ml}$, a następnie o ok. $1 \log$ jtk/ml po 3-godzinnej inkubacji w soku jelitowym. Zgodnie z tym można wnioskować, że dane szczepy wykazują dobrą oporność na zastosowane warunki panujące w modelowym układzie pokarmowym człowieka.

Stwierdzono, że obniżenie $\mathrm{pH}$ soku żołądkowego z 2,5 do 2,0 spowodowało istotną zmianę w przeżywalności bakterii Lactobacillus spp. w soku żołądkowym (o ok. $4 \log$ jtk/ml), a następnie jelitowym (o ok. $1 \log$ jtk/ml). Ponadto we wszystkich wariantach doświadczalnych, w których $\mathrm{pH}$ soku żołądkowego wynosiło 2,0, odnotowano istotne obniżenie liczby bakterii po $2 \mathrm{~h}$ inkubacji, natomiast $\mathrm{w}$ przypadku zastosowania soku żołądkowego o $\mathrm{pH}=2,5$ efekt ten obserwowany był dopiero po $5 \mathrm{~h}$ inkubacji. Uważa się, że gatunek $L b$. plantarum jest oporny na niskie $\mathrm{pH}$ soku żołądkowego i sole kwasów żółciowych [4]. Podobne wyniki otrzymali wcześniej inni autorzy [1,12], którzy podkreślali kluczowy wpływ kwasowości na przeżywalność bakterii z rodzaju Lactobacillus. Z drugiej strony stabilizacja żywotności, którą obserwowano w warunkach soku jelitowego, wskazuje na to, że testowane szczepy $L b$. plantarum mogą dotrzeć do okrężnicy w odpowiedniej liczbie żywych komórek (ok. $6 \log \mathrm{jtk} / \mathrm{ml}$ ), nawet po ekspozycji na działanie szkodliwego czynnika w postaci kwasu o $\mathrm{pH}=2,0$. 


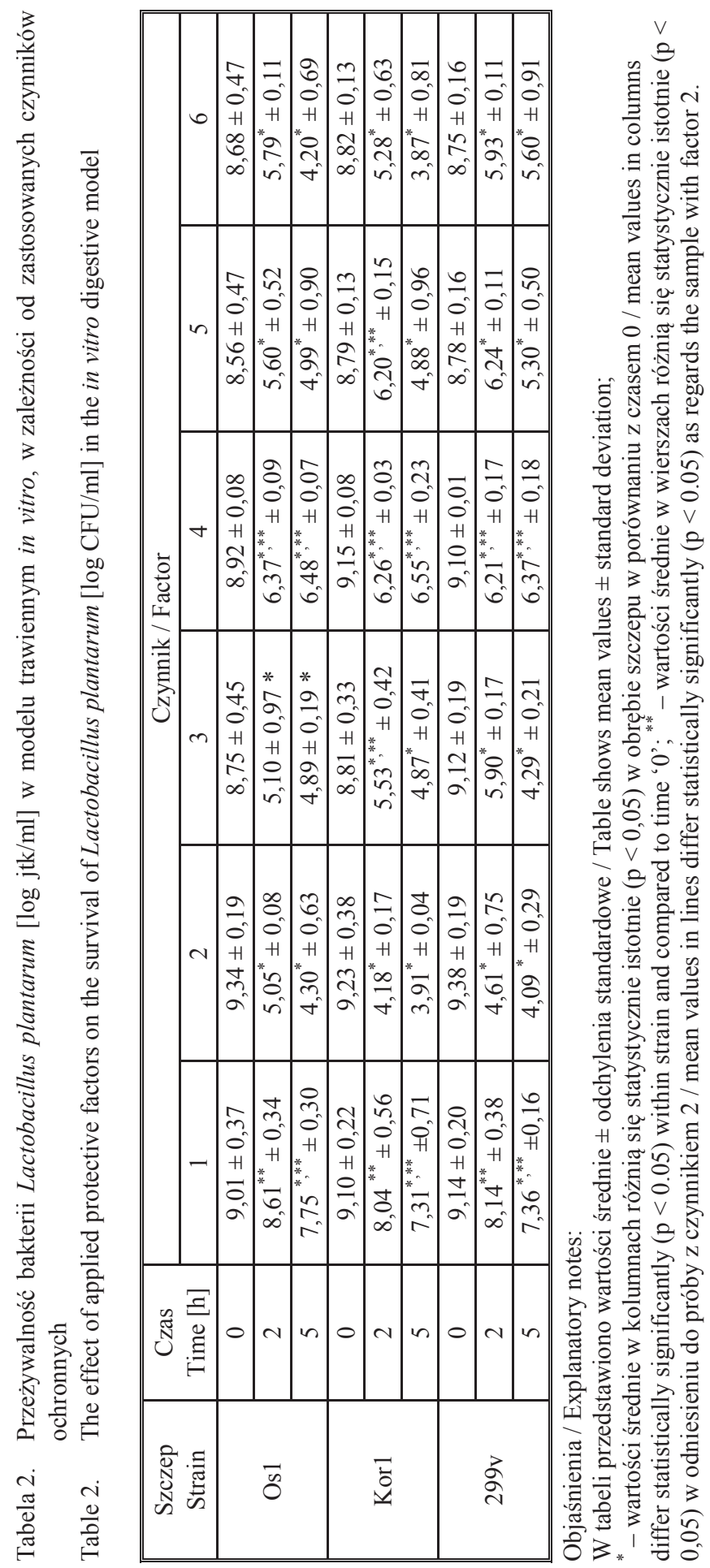


Uważa się, że bakterie fermentacji mlekowej wzrastają i pozostają żywe przy pH w zakresie $4,5 \div 7,0$ [10]. Jednakże przy obniżonym pH środowiska uruchamiane zostają mechanizmy, dzięki którym pH cytoplazmatyczne komórek pozostaje bardziej alkaliczne niż środowiska. Bakterie fermentacji mlekowej szybko wydzielają kwas z komórek za pośrednictwem pomp protonowych F1F0-ATPaza oraz systemów: deiminazy argininy ADI (ang. arginine deiminase), dekarboksylazy glutaminianu GAD (ang. glutamatede carboxylase) i zdolności do wytwarzania chaperonów. Ponadto błony biologiczne są względnie nieprzepuszczalne dla protonów oraz cząsteczek kwasu. $\mathrm{W}$ ten sposób tworzy się gradient $\mathrm{pH}$ pomiędzy cytoplazmą a środowiskiem ich bytowania $[3,10]$. W wielu badaniach wykazano, że oporność na niskie $\mathrm{pH}$ jest szczepozależna $[2,18,26]$, co potwierdzono także w badaniach własnych.

W wyniku przeprowadzonych badań zaobserwowano ochronny wpływ czynników żywieniowych na przeżywalność $L b$. plantarum podczas modelowego pasażu żołądkowo-jelitowego. W celu wykazania efektu ochronnego zastosowano warunki badań (2) z obniżonym pH soku żołądkowego do wartości 2,0. Statystycznie istotny $(\mathrm{p}<0,05)$ wpływ zaobserwowano w wariancie 4 doświadczenia, w którym zastosowano śmietankę o zawartości tłuszczu $36 \%$. Dodatkowo w wariancie tym zaobserwowano wyższą liczbę bakterii po $5 \mathrm{~h}$ niż po $2 \mathrm{~h}$ inkubacji, niezależnie od zastosowanego szczepu bakterii, co dowodzi, że komórki były w stanie rozpoczą́ proces regeneracji i rozmnażać się w soku jelitowym. W przypadku zastosowania mleka (3) o zawartości thuszczu 3,2 \% efekt ochronny był istotny jedynie w przypadku szczepu Kor1 po pasażu żołądkowym. Tłuszcz mleczny zawarty w śmietance i mleku wpłynął ochronnie na komórki bakterii. Z publikacji Klewickiej i wsp. [15] wiadomo, że tłuszcz zawarty w żywności przyczynia się do spowolnienia ruchów jelit, a tym samym do dłuższego pasażu i nawet namnażania się bakterii [15]. Ponadto białka mleka mają właściwości buforujące, co sprzyja podwyższaniu pH w soku żołądkowym i może przyczyniać się do lepszej przeżywalności bakterii w trakcie trawienia [8]. Uważa się, że mleko i produkty mleczne należą do grupy najlepszych nośników bakterii probiotycznych ze względu na przytoczone właściwości [9]. Horáčková i wsp. [13] potwierdzili to w swoim badaniu, w którym wykazali, że liczba komórek bakterii Lactobacillus po inkubacji w sokach trawiennych z dodatkiem mleka uległa obniżeniu o $1 \div 3$ jednostek logarytmicznych w porównaniu z próbą kontrolną bez dodatku mleka, w której liczba komórek bakterii obniżyła się o $3 \div 5$ jednostek logarytmicznych. Również Klewicka i wsp. [15] analizowali przeżywalność bakterii Lactobacillus w preparacie probiotycznym w modelowym przewodzie pokarmowym człowieka przy udziale dodatku żywności. Autorki stwierdziły, że matryca żywieniowa ma korzystny wpływ na przeżywalność bakterii, gdyż tworzy warunki ochronne dla komórek bakterii. Najlepszy efekt ochronny wykazał preparat mlekozastępczy, co wynikało z jego składu, który tworzyły: oleje roślinne, syrop glukozowy, hydrolizat kazeiny, witaminy oraz składniki mineralne. Z 
kolei Rzepkowska i wsp. [22] w badaniach nad przeżywalnością szczepów Lactobacillus spp. wyizolowanych z żywności w warunkach modelowego przewodu pokarmowego, z zastosowaniem medium żywnościowego w postaci mleka w proszku, mleka UHT o zawartości tłuszczu 3,2 \%, bulionu wołowego oraz bulionu MRS wykazali, że najlepszy efekt ochronny uzyskano w przypadku mleka UHT. Powyższa obserwacja ma związek z pozytywnym działaniem składników mleka (głównie białka, w tym białka serwatkowego) na żywotność komórek bakterii mlekowych.

Zastosowanie prebiotyków - warianty 5 i 6 , również wpłynęło na poprawę przeżywalności bakterii w trakcie pasażu żołądkowo-jelitowego. Istotny wpływ zaobserwowano w przypadku szczepu Kor1, przy zastosowaniu inuliny jako czynnika ochronnego po pasażu żołądkowym. Zaobserwowano, że liczba komórek bakterii $L b$. plantarum Kor 1, które zawieszono w 10-procentowym roztworze inuliny, obniżyła się o 2,6 log jtk/ml, natomiast komórki tych samych bakterii bez dodatku czynnika ochronnego (2) obniżyły swoją liczbę o $5,0 \mathrm{log}$ jtk/ml po $2 \mathrm{~h}$ inkubacji w soku żołądkowym. Podobny efekt obserwowano w przypadku zastosowania 10-procentowego roztworu oligofruktozy jako czynnika ochronnego. Liczba komórek bakterii ulegała redukcji średnio o $2,8 \div 3,5 \mathrm{log} \mathrm{jtk} / \mathrm{ml}$ po pasażu żołądkowym i kolejno o średnio $0,3 \div$ 1,6 log jtk/ml po pasażu jelitowym, w zależności od zastosowanego szczepu (tab. 2).

Inulina jest polisacharydem zapasowym, który zawiera cząsteczki glukozy i fruktozy. Oligofruktoza zaś jest związkiem, który składa się z dwóch do pięciu cząsteczek fruktozy. Są one połączone wiązaniem glikozydowym i powstają wskutek częściowej hydrolizy inuliny przy użyciu enzymu endonukleazy. Oligofruktoza, dzięki krótszemu w porównaniu $\mathrm{z}$ inuliną łańcuchowi fruktozowemu, ma właściwości technologiczne porównywalne do tych, które charakteryzują cukier i syrop glukozowy. Inulina z kolei, dzięki swoim właściwościom, pełni technologicznie rolę zamiennika tłuszczu i cukru [5].Właściwości chemiczne roztworów prebiotyków mogą także działać ochronnie na komórki bakterii probiotycznych. Krasaekoopt i Watcharapoka [16] wykazali, że dodatek galaktooligosacharydów $(0,3 \%)$ stanowił ochronę w przypadku mikrokapsułkowania bakterii $L$ b. acidophilus 5 i $L b$. casei 01, powodując redukcję jedynie o 3,1 i 2,9 log $\mathrm{jtk} / \mathrm{ml}$ po inkubacji w symulowanym soku żołądkowym ( $\mathrm{pH} 1,55)$, a następnie jelitowym, zawierającym 0,6 \% soli kwasów żółciowych. Z kolei Gandomi i wsp. [11] stwierdzili, że kapsułkowanie Lb. rhamnosus poprawiło żywotność bakterii $(27,7 \%$ populacji bakterii przeżyło modelowy pasaż żołądkowo-jelitowy), a ponadto wykazali, że dodatek inuliny znacząco wpłynął $(\mathrm{p}<0,05)$ na poprawę żywotności bakterii kapsułkowanych [11].

Analiza składowych głównych zastosowana do danych uzyskanych w niniejszym badaniu pozwoliła na zidentyfikowanie 6 składowych głównych, z których dwie pierwsze tłumaczą 87,21 \% zmienności zmiennych. Projekcję dwóch pierwszych skła- 
dowych na płaszczyznę czynników przedstawiono na rys. 1. Z kolei na rys. 2. przedstawiono wyniki analizy skupień.

Na wykresie można zaobserwować dwie wyraźnie jednorodne grupy. Przypadki reprezentujące czynniki ochronne 3, 5 i 6 są położone blisko siebie, co świadczy o ich silnym związku i podobnym efekcie działania ochronnego mleka UHT 3,2\%, 10-procenrowych roztworów inuliny i oligofruktozy. Analiza skupień (rys. 2) również potwierdza silny związek pomiędzy tymi czynnikami. Z kolei zastosowanie śmietanki $36 \%$ (4) miało podobny wpływ jak podwyższenie pH o 0,5 wartości (1). Należy także

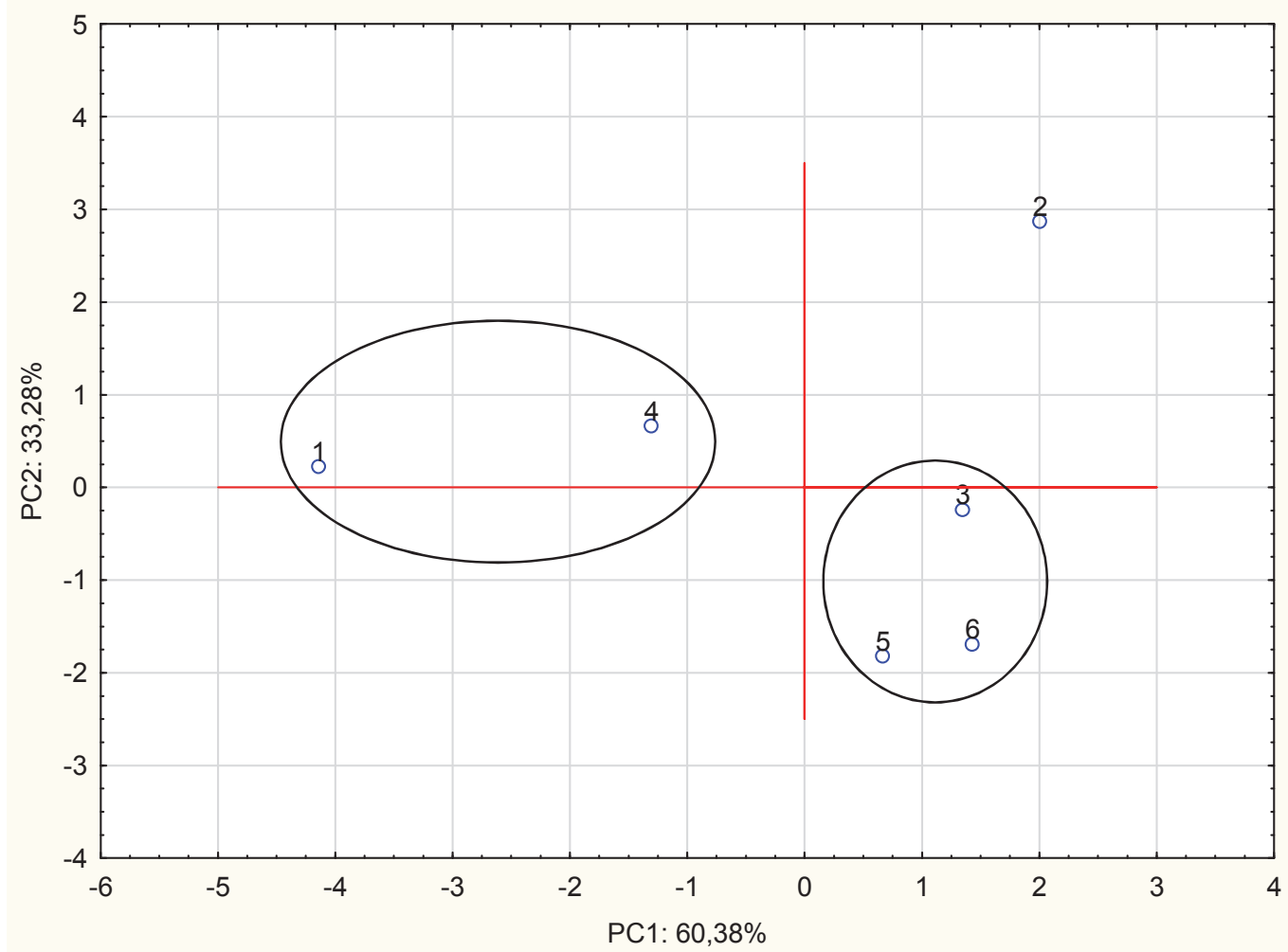

Objaśnienia / Explanatory notes:

1 - warunki standardowe, sok żołądkowy o $\mathrm{pH}=2,5$ / standard conditions, gastric juice with $\mathrm{pH}=2.5$;

2 - warunki standardowe, sok żołądkowy o $\mathrm{pH}=2,0$ / standard conditions, gastric juice with $\mathrm{pH}=2.0$;

3 - warunki standardowe (2) z dodatkiem mleka / standard conditions (2) with milk added;

4 - warunki standardowe (2) z dodatkiem śmietanki / standard conditions (2) with cream added;

5 - warunki standardowe (2) z dodatkiem inuliny / standard conditions (2) with inulin added;

6 - warunki standardowe (2) z dodatkiem oligofruktozy / standard conditions (2) with oligofructose added.

Rys. 1. Rozkład PCA przypadków na płaszczyznę czynników

Fig. 1. Distribution of PCA cases onto plane of principal components 
zauważyć, że warunki (2) o obniżonym pH soku żołądkowego do wartości 2,0 całkiem odstają od pozostałych przypadków, co wskazuje, że warunki te były w silnym stopniu inaktywujące dla komórek bakterii i nie chroniły ich przed szkodliwym działaniem czynników środowiskowych.

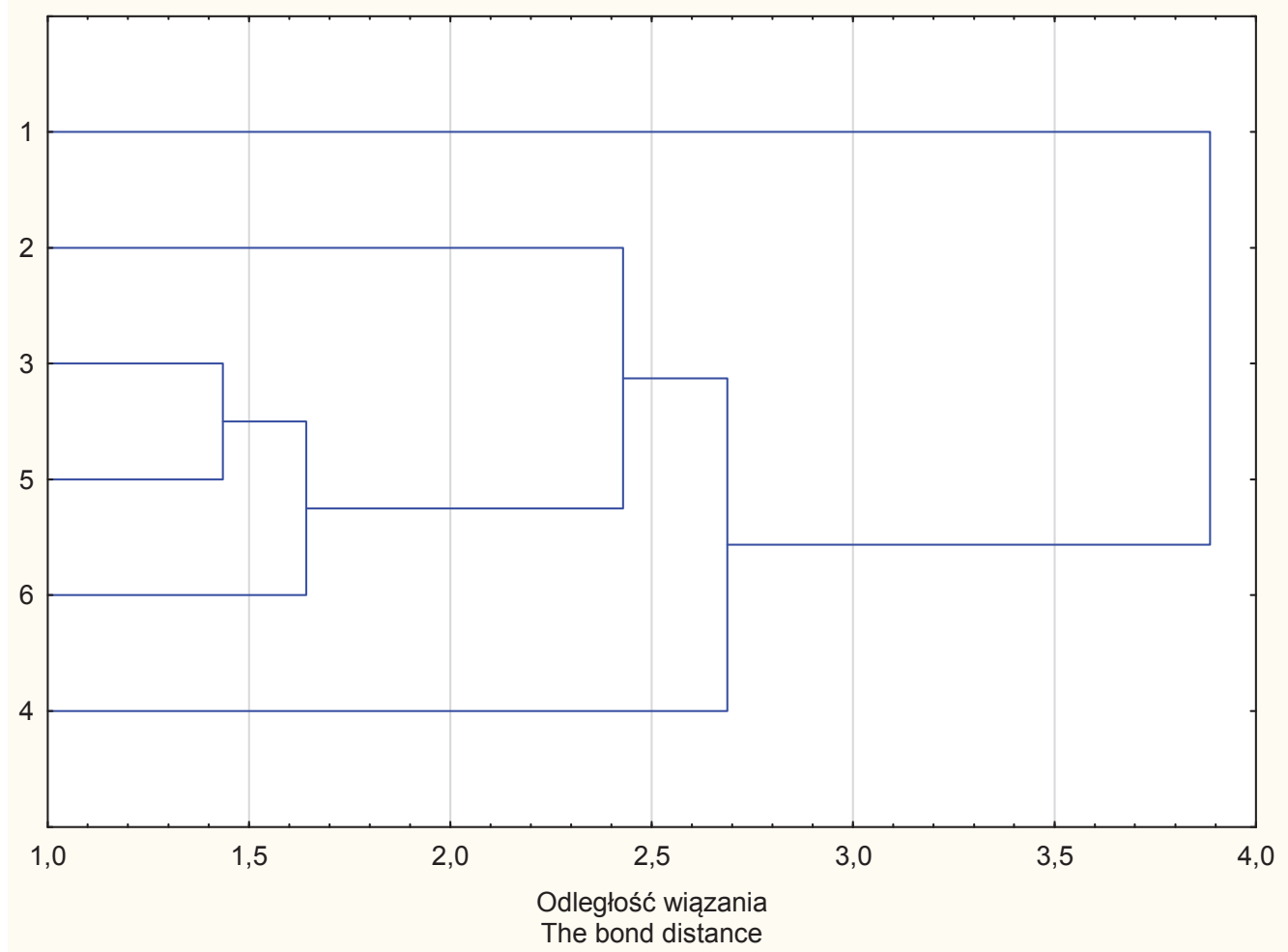

Objaśnienia jak pod rys. 1. / Explanatory notes as in Fig. 1.

Rys. 2. Analiza skupień zastosowanych w badaniach czynników ochronnych w porównaniu z warunkami referencyjnymi

Fig. 2. Cluster analysis of protective factors used in the study compared to the reference conditions

Podsumowując, można stwierdzić, że bakterie z gatunku Lactobacillus plantarum zastosowane w badaniach wykazują znaczną oporność na warunki panujące w modelowym przewodzie pokarmowym. Nie wykazano różnic pomiędzy bakteriami wyizolowanymi z żywności (Os1 i Kor1) a szczepem bakterii probiotycznych pochodzenia ludzkiego (299v). Świadczy to o potencjalnych właściwościach tych szczepów i weryfikuje negatywnie tezę, że szczepy bakterii kandydujące do miana probiotyku powinny być izolowane wyłącznie z przewodu pokarmowego człowieka, m.in. ze względu na „wrodzoną” oporność na warunki panujące w przewodzie pokarmowym, co było podnoszone w publikacjach $[19,24]$. W ostatnich latach, wobec nowych dowodów nau- 
kowych odchodzi się od tej wyłączności i dopuszcza do badań szczepy izolowane $\mathrm{z}$ innych, niekonwencjonalnych źródeł [25].

Wykazano także, że projektowanie żywności probiotycznej powinno uwzględniać takie czynniki, jak właściwy nośnik żywnościowy. Uważa się, że mleko i produkty mleczne są najlepszym nośnikiem bakterii probiotycznych ze względu na właściwości buforujące białek mleka i zawartość tłuszczu, jednak zastosowanie prebiotyków umożliwia uzyskanie porównywalnych efektów. Inulina i oligofruktoza mogą także pełnić funkcję ochronną dla bakterii probiotycznych w żywności.

\section{Wnioski}

1. Najsilniejszy efekt ochronny na przeżywalność badanych komórek bakterii Lactobacillus plantarum wykazał tłuszcz mleczny w postaci śmietanki $(36 \%)$ oraz w stopniu średnim polisacharydy (10-procentowy roztwory inuliny i oligofruktozy) oraz mleko $(3,2 \%)$.

2. Badane szczepy wyizolowane z żywności (Kor1 oraz Os1) charakteryzowały się podobnymi właściwościami co szczep referencyjny $L$ b. plantarum $299 \mathrm{v}$, co może świadczyć o potencjalnych właściwościach probiotycznych w tym zakresie.

3. Przeprowadzone badania wskazują na zasadność dalszych badań potwierdzających probiotyczne właściwości i potencjalne zastosowanie jako probiotyków bakterii wyizolowanych z żywności fermentowanej.

Praca finansowana przez Ministerstwo Nauki i Szkolnictwa Wyższego w ramach środków na utrzymanie potencjału badawczego Wydziału Nauk o Żywieniu Człowieka i Konsumpcji $S G G W$ w Warszawie.

\section{Literatura}

[1] Arena M.P., Caggianiello G., Fiocco D., Russo P., Torelli M., Spano G., Capozzi V.: Barley $\beta$-glucans-containing food enhances probiotic performances of beneficial bacteria. Int. J. Mol. Sci., 2014, 15, 3026-3039

[2] Caggia C., De Angelis M., Pitino I., Pino A., Randazzo C.L.: Probiotic features of Lactobacillus strains isolated from Ragusano and Pecorino Siciliano cheeses. Food Microbiol., 2015, 50, 109-117.

[3] Cotter P.D., Hill C.: Surviving the acid test: Responses of gram-positive bacteria to low pH. Microb. Mol. Biol. Rev., 2003, 67 (3), 429-453.

[4] De Vries M.C., Vaughan E.E., Kleerebezem M., de Vos W.M.: Lactobacillus plantarum - survival, functional and potential probiotic properties in the human intestinal tract. Int. Dairy J., 2006, 16 (9), 1018-1028.

[5] Drabińska N., Zieliński H., Krupa-Kozak U.: Technological benefits of inulin-type fructans application in gluten-free products - A review. Trends Food Sci. Technol., 2016, 56, 149-157.

[6] FAO/WHO.: Probiotics in food. Health and nutritional properties and guidelines for evaluation. FAO, Rome 2002. 
[7] FAO: FAO Technical Meeting on Prebiotics. FAO, Rome 2007.

[8] Fox P.F., Uniacke-Lowe T., McSweeney P.L.H., O’Mahony J.A.: Physical properties of milk. In: Dairy Chemistry and Biochemistry. $2^{\text {nd }}$ ed. Springer International Publishing, Cham 2015, pp. 321343.

[9] Gahruie H.H.: Yogurt. The most suitable carrier for increasing bioavailability of minerals. Progress Nutr., 2018, 20 (2-S), 294-296.

[10] Gajewska J., Błaszczyk M.K.: Probiotyczne bakterie fermentacji mlekowej (LAB). Post. Mikrobiol. 2012, 51(1), 55-65.

[11] Gandomi H., Abbaszadeh S., Misaghi A., Bokaie S., Noori N.: Effect of chitosan-alginate encapsulation with inulin on survival of Lactobacillus rhamnosus GG during apple juice storage and under simulated gastrointestinal conditions. LWT - Food Sci. Technol., 2016, 69, 365-371.

[12] Gheziel C., Russo P., Arena M.P., Spano G., Ouzari H.I., Kheroua O., Saidi D., Fiocco D., Kaddouri H., Capozzi V.: Evaluating the probiotic potential of Lactobacillus plantarum strains from Algerian infant feces: Towards the design of probiotic starter cultures tailored for developing countries. Probiotics Antimicrob. Proteins, 2019, 11(1), 113-123.

[13] Horáčková S., Žaludová K., Plocková M.: Stability of selected Lactobacilli in the conditions simulating those in the gastrointestinal tract. Czech J. Food Sci., 2011, 29, 30-35.

[14] Kerry R.G., Patra J.K., Gouda S., Park Y., Shin H.S., Das G.: Benefaction of probiotics for human health: A review. J. Food Drug Analysis, 2018, 26 (3), 927-939.

[15] Klewicka E., Śliżewska K., Nowak A.: Ocena przeżywalności bakterii Lactobacillus zawartych w preparacie probiotycznym podczas pasażu w symulowanym przewodzie pokarmowym. Żywność. Nauka. Technologia. Jakość, 2014, 6 (97), 170-181.

[16] Krasaekoopt W., Watcharapoka S.: Effect of addition of inulin and galactooligosaccharide on the survival of microencapsulated probiotics in alginate beads coated with chitosan in simulated digestive system, yogurt and fruit juice. LWT - Food Sci. Technol., 2014, 57 (2), 761-766.

[17] Markowiak P., Śliżewska K.: Effects of probiotics, prebiotics, and synbiotics on human health. Nutrients, 2017, 9 (9), \#1021. DOI: 10.3390/nu9091021.

[18] Mathara J.M., Schillinger U., Guigas C., Franz C., Kutima P.M., Mbugua S.K., Shin H.-K., Holzapfel W.H.: Functional characteristics of Lactobacillus spp. from traditional Maasai fermented milk products in Kenya. Int. J. Food Microbiol., 2008, 126, 57-64.

[19] Nowak A., Śliżewska K., Libudzisz Z.: Probiotyki - historia i mechanizmy działania. Żywność. Nauka. Technologia. Jakość, 2010, 4 (71), 5-19.

[20] Ołdak A., Zielińska D., Rzepkowska A., Kołożyn-Krajewska D.: Comparison of antibacterial activity of Lactobacillus plantarum strains isolated from two different kinds of regional cheeses from Poland: Oscypek and korycinski cheese. BioMed. Res. Int., 2017, \#6820369. DOI: 10.1155/2017/6820369.

[21] PN-ISO 15214:2002. Mikrobiologia żywności i pasz. Horyzontalna metoda oznaczania liczby mezofilnych bakterii fermentacji mlekowej. Metoda płytkowa w temperaturze $30{ }^{\circ} \mathrm{C}$.

[22] Rzepkowska A., Zielińska D., Kołożyn-Krajewska D.: Przeżywalność szczepów Lactobacillus wyizolowanych z żywności w warunkach modelowego przewodu pokarmowego. Żywność. Nauka. Technologia. Jakość, 2015, 3 (100), 42-52.

[23] Sanders M.E.: Probiotics: The concept. In: WGO Handbook on Gut Microbes. The WGO Foundation, Milwakee, USA, 2014, pp. 39-42.

[24] Sanders M.E.: Probiotics: Definition, sources, selection, and uses. Clin. Infections Diseases, 2008, 46(Suppl. 2), S58-S61.

[25] Zielińska D., Kołożyn-Krajewska D.: Food-origin lactic acid bacteria may exhibit probiotic properties. Biomed Res. Int., 2018, \#5063185. DOI: 10.1155/2018/5063185. 
[26] Zielińska D., Rzepkowska A., Radawska A., Zieliński K.: In vitro screening of selected probiotic properties of Lactobacillus strains isolated from traditional fermented cabbage and cucumber. Curr. Microbiol., 2015, 70 (2), 183-194.

\section{EFFECT OF SELECTED FOOD INGREDIENTS ON BEHAVIOUR OF LACTOBACILLUS BACTERIA IN GASTRO-INTESTINAL TRACT - IN VITRO STUDY}

\section{S u m m a ry}

The objective of the research study was to assess the survival of selected Lactobacillus bacteria strains isolated from oscypek and korycin cheese under the in vitro conditions of a gastrointestinal tract model and depending on the food additives used. The scope of the research study included the assessment of bacterial survival after 2 and $5 \mathrm{~h}$ incubation in a model system that simulated the gastrointestinal tract and depending on the protective additive used: UHT milk (3.2\% of fat), cream (36\% of fat), $10 \%$ solutions of inulin and oligofructose. It was shown that the strains tested were resistant to the gastric juice with a $\mathrm{pH}$ value of 2.5 , whereas the gastric juice model with $\mathrm{pH}$ of 2.0 caused the viability of those bacteria to decrease by ca. 5 logarithmic units on average after $2 \mathrm{~h}$ incubation in the gastric juice. The UHT milk showed a slight protective effect on the survival of bacterial cells, which could be compared to the effect of inulin and oligofructose in a low pH environment, with the applied research method. In contrast, a significant protective effect was reported on the survival of bacterial cells of the tested strains in the case of using $36 \%$ cream; this is most likely related to a higher fat content compared to its content in the milk. Test strains, Lb. plantarum (Kor1 and Os1) isolated from food, were characterised by the properties similar to those of the reference $L$ b. plantarum $299 \mathrm{v}$ strain; this may indicate potential probiotic properties in this area. The conducted studies indicate the validity of further studies to confirm the probiotic properties of bacteria isolated from fermented foods and their potential use as probiotics.

Key words: probiotics, Lactobacillus, in vitro tests, gastrointestinal tract, survival 